\title{
PEMANFAATAN, PERSEPSI DAN PARTISIPASI MASYARAKAT TERHADAP PELESTARIAN EKOSISTEM PESISIR DI DISTRIK MANOKWARI SELATAN
}

\author{
Pattern Use, Perception and Participation of Coastal Communities on \\ Ecosystem Conservation in South Manokwari District
}

\author{
Konstanpina M. Okoseray ${ }^{1}$, Nurhani Widiastuti ${ }^{1 *}$, dan Dedi Parenden ${ }^{1}$ \\ ${ }^{1}$ Jurusan Perikanan, FPIK UNIPA, Manokwari, 98314, Indonesia \\ *Korespondensi : n_widiast@yahoo.com
}

\begin{abstract}
ABSTRAK
Selain kajian ekologi, kajian sosial ekonomi tentang peran masyarakat dalam memanfaatkan potensi sumberdaya pesisir juga perlu dilakukan untuk mendesain model pengelolaan pesisir yang tepat. Tujuan dari penelitian ini adalah untuk mengetahui bentuk pemanfaatan sumberdaya pesisir oleh masyarakat di Distrik Manokwari Selatan dan untuk mengetahui persepsi dan partisipasi masyarakat tentang pelestarian ekosistem pesisir. Penelitian berlangsung pada April hingga Juli 2013, bertempat di Rendani, Sowi IV, dan Arfai, Distrik Manokwari Selatan. Pengumpulan data dilakukan dengan observasi dan wawancara. Pengolahan data persepsi secara tabulasi yang dinyatakan dalam persen (\%) dan disajikan dalam bentuk diagram, selanjutnya dilakukan analisa interpretasi dengan menggunakan referensi terkait. Hasil penelitian memberi informasi bahwa masyarakat telah memanfaatkan mangrove dan karang untuk berbagai peruntukan, sedangkan lamun belum dimanfaatkan. Terdapat bentuk pemanfaatan yang bersifat merusak seperti penebangan mangrove dan penambangan karang. Responden menilai bahwa kondisi lingkungan pesisir telah rusak, terutama ekosistem mangrove $(97 \%)$ dan terumbu karang $(83 \%)$. Permasalahan yang paling dominan adalah berkurangnya sumberdaya ikan $(98 \%)$ dan terkontaminasinya laut oleh sampah (97\%). Responden juga menilai bahwa perlu ada upaya pelestarian sumberdaya alam pesisir dan lautan seperti penanaman mangrove (47\%) dan karang (32\%). Partisipasi masyarakat dalam pelestarian ekosistem pesisir tergolong rendah, baru sampai pada tahap restorasi, dan termasuk partisipasi yang dimobilisasi.
\end{abstract}

Kata kunci : Persepsei masyarakat, pemanfaatan ekosistem, Manokwari selatan

\begin{abstract}
Beside the study of ecology, socio-economic studies on the role of the community in exploiting the coastal resources is also necessary to design the right model of coastal management. The purpose of this study was to determine the shape of coastal resource use by communities in Distrik Manokwari Selatan and to know the perception and public participation on the preservation of coastal ecosystems. The study lasted from April to July 2013, at Rendani, Sowi IV, and Arfai, Distrik Manokwari Selatan. The data collection is done by observation and interviews. Data processing perception of tabulation expressed in percent $(\%)$ and are presented in chart, then analyzed using the interpretation of related references. The results of this study provide information that people use mangrove and coral, while seagrass untapped. There are forms of destructive using such as the harvesting of mangroves and coral mining. Respondents judged that the condition of the coastal environment has been damaged, especially mangrove ecosystems (97\%) and coral reefs (83\%). The problems most dominant is the reduction of fish resources $(98 \%)$ and contamination of the sea by garbage $(97 \%)$. Respondents also considered that there should
\end{abstract}


be efforts to conserve coastal and marine natural resources such as mangrove planting (47\%) and Coral (32\%). Community participation in the preservation of coastal ecosystems is low, to reach the phase of restoration, and included participation mobilized.

Key words : Social perceptions, ecosystem utilization, Manokwari Selatan

\section{PENDAHULUAN}

Manokwari merupakan daerah pesisir yang memiliki potensi pesisir dan laut baik berupa ekosistem terumbu karang, ekosistem padang lamun, dan ekosistem mangrove yang dapat dimanfaatkan untuk berbagai kegiatan penelitian, ilmu pengetahuan, pariwisata dan perikanan.

Masyarakat nelayan di Manokwari mem-pertahankan hidupnya dengan bergantung pada hasil laut melalui kegiatan perikanan tangkap maupun perikanan non tangkap. Seiring dengan pembangunan Manokwari sebagai Ibu Kota Propinsi Papua Barat, maka pembukaan lahan di daratan semakin luas dan secara langsung maupun tidak langsung berpengaruh terhadap degradasi ekosistem pesisir dan laut. Di satu sisi, tekanan ekonomi menyebabkan nelayan cenderung memanfaatkan cara-cara penangkapan yang tidak ramah lingkungan. Meningkatnya jumlah penduduk juga menyebabkan kenaikan permintaan terhadap sumberdaya ikan. Hal ini menyebabkan pola pemanfaatan sumberdaya perikanan yang berlebihan dan tidak memperhatikan aspek daya dukung lingkungan sehingga dapat mengganggu ekosistem pesisir dan laut.

Kerusakan ekosistem pesisir secara langsung maupun tidak langsung dapat berpengaruh terhadap kesejahteraan masyarakat pesisir. Terkait dengan kelestarian ekosistem pesisir Manokwari, perlu ada upaya konser-vasi guna mencegah kerusakan yang semakin parah. Berbagai kajian ekologi telah dila-kukan, namun belum terdapat kajian tentang kondisi sosial ekonomi terkait upaya peles-tarian ekosistem pesisir. Aspek sosial ekono-mi masyarakat memiliki peran yang besar dalam pengelolaan dan pemanfaatan sumberdaya pesisir, karena dapat menjawab bagaimana mestinya peran masyarakat dalam memanfaatkan potensi sumberdaya pesisir yang ada di Manokwari Selatan dan kendala apa yang dihadapi masyarakat dalam pemanfaatan sumberdaya pesisir, serta bagaimana persepsi dan partisipasi masyarakat pesisir di Distrik Manokwari Selatan tentang pelestarian ekosistem pesisir.

Tujuan dari penelitian ini adalah untuk mengetahui bentuk-bentuk pemanfaatan sumberdaya pesisir masyarakat pesisir Distrik Manokwari Selatan dan untuk mengetahui persepsi dan partisipasi masyarakat pesisir tentang pelestarian ekosistem pesisir.

\section{METODE PENELITIAN}

\section{Waktu dan Tempat}

Penelitian ini berlangsung pada bulan April hingga Juli 2013. Lokasi penelitian bertempat di Rendani, Sowi IV dan Arfai, Distrik Manokwari Selatan. Wilayah ini di-pilih karena mayoritas penduduknya me-manfaatkan sumberdaya pesisir dan laut di sekitarnya untuk keperluan konsumsi keluarga dan sumber penghasilan. Masyarakat di wilayah ini juga diperhadapkan pada pilihan antara konservasi dan penggunaan lahan yang massif karena pembangunan. 


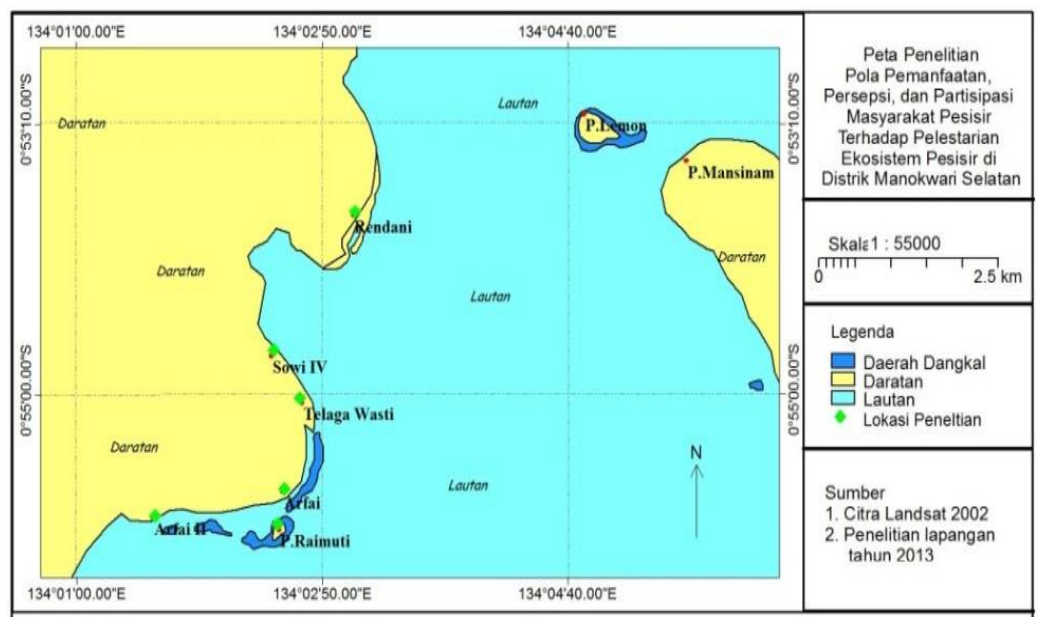

Gambar 1. Peta Lokasi Penelitian(sumber.google earth,2013)

\section{Alat dan Bahan}

Alat dan bahan yang digunakan dalam penelitian ini terdiri dari GPS receiver, kamera dgital, alat tulis menulis, alat perekam, kuisioner, dan bahan kontak.

\section{Variabel Pengamatan dan Kriteria Pe- ngukuran}

Persepsi dan partisipasi masyarakat ter-hadap konservasi ekosistem pesisir dianalisa dari indikator berikut:

a. Pemanfaatan sumberdaya pesisir (mangrove, lamun dan terumbu karang)

b. Persepsi akan pelestarian ekosistem pesisir

c. Partisipasi dalam upaya konservasi

Untuk mengetahui persepsi dan partisipasi masyarakat (responden), pen- dekatan pengukuran dilakukan dengan menela-ah/menafsirkan jawaban responden dalam kaitannya dengan konservasi ekosistem pesisir dan pemberian alternatif jawaban untuk setiap indikator persepsi dan partisipasi. Data yang diperoleh dari kuesioner adalah data ordinal yang mengukur tingkatan atau gradasi dari sangat positif sampai sangat negatif. Skala yang digunakan untuk mengukur sikap, pendapat dan persepsi seseorang atau seke-lompok orang tentang fenomena sosial yaitu skala likert, sehingga daftar pertanyaan yang digunakan adalah daftar pertanyaan likert (likert- type questions). Untuk keperluan pengolahan data, maka jawaban diberi skor, seperti tampak pada Tabel 1.

Tabel 1. Skoring Likert Question

\begin{tabular}{lcc}
\hline \multirow{2}{*}{ Pilihan Jawaban } & \multicolumn{2}{c}{ Skor masing-masing Pernyataan } \\
\cline { 2 - 3 } & $\begin{array}{c}\text { Pernyataan } \\
\text { Positif }\end{array}$ & $\begin{array}{c}\text { Pernyataan } \\
\text { Negatif }\end{array}$ \\
\hline Sangat setuju/sangat tahu/sangat positif & 3 & 0 \\
Setuju/tahu/positif & 2 & 1 \\
Tidak setuju/cukup tahu/tidak & 1 & 2 \\
pernah/negative & & 3 \\
Sangat tidak setuju/tidak tahu/tidak pernah & 0 & \\
\hline
\end{tabular}

\section{Teknik Pengumpulan Data}

Teknik pengumpulan data dilakukan dengan cara observasi langsung di lapangan, terdiri dari survei rumah tangga dan wawancara perorangan. Terdapat dua jenis kuesioner yang dibuat, yaitu (a) kuesioner untuk rumah tangga dan (b) kuesioner untuk survei individu. Kuesioner 
rumah tangga akan dikembangkan untuk mengetahui karakteristik rumah tangga perikanan di wilayah survei. Kuesioner individu untuk mengetahui penge-tahuan sikap dan tingkah laku individu responden terhadap pemanfaatan sumberdaya maupun persepsi dan partisipasi dalam pe-lestarian ekosistem pesisir.

\section{Pemilihan Responden}

Pengumpulan data untuk monitoring ini dilakukan dalam dua tahap yakni survei rumah tangga dan wawancara perorangan. Oleh karena itu, pemilihan responden juga akan dilakukan dalam dua tahapan, yaitu survei rumah tangga dan wawancara perorangan. Tiga puluh rumah tangga (RT) per kampung yang berdomisili di pesisir pantai dipilih untuk diwawancarai. Semua anggota rumah tangga yang berusia antara lebih dari 15 tahun dan tidak bepergian dalam jangka waktu lama atau selama tenggang waktu pelaksanaan penelitian, memenuhi syarat untuk diwawancarai. Seseorang dikatakan anggota rumah tangga apabila orang tersebut hidup dan tinggal di dalam rumah tangga secara permanen dan menggunakan dapur yang sama di dalam rumah tangga. Pada saat pengambilan data, 60 RT di Arfai dan Sowi IV terpenuhi, namun di Rendani hanya terdapat 6 RT yang bertempat tinggal di pesisir yang beraktivitas di pesisir dan laut. Selain responden masyarakat pesisir, wawancara juga dilakukan terhadap tokoh masyarakat, tokoh adat dan tokoh agama yang dinilai memiliki pengaruh di masyarakat dalam pengambilan keputusan.

\section{Pengolahan dan Analisa Data}

Pengolahan data dilakukan secara deskriptif tabulasi dan analisis interpretatif. Analisis secara tabulasi untuk mengetahui persepsi dan sikap masyarakat terhadap keberadaan ekosistem pesisir yang dinyatakan dalam persen (\%) dan disajikan dalam bentuk diagram, selanjutnya dilakukan interpretasi dengan menggunakan referensi terkait topik penelitian.

\section{HASIL DAN PEMBAHASAN}

\section{Pemanfaatan Sumberdaya Ekosistem Pesisir}

Masyarakat pesisir di lokasi penelitian umumnya memanfaatkan sumberdaya pesisir untuk memenuhi kebutuhan hidup. Bengen (2003) menyatakan bahwa manfaat ekonomi yang dapat diperoleh dari hutan mangrove adalah kayu untuk bahan bangunan, kayu bakar, dan bahan arang. Bentuk pemanfaatan tersebut umumnya juga dilakukan oleh masyarakat pesisir di Distrik Manokwari Selatan. Pada gambar 2, tampak persentase penggunaan mangrove sebagai bahan bangunan berdasarkan lokasi. Pemanfaatan mangrove sebagai tiang rumah dilakukan oleh sebagian masyarakat di Rendani (16\%), dan Sowi IV (47\%). Jenis yang umum dimanfaatkan sebagai bahan bangunan adalah Rhizopora sp. dan Lumnitzera sp.

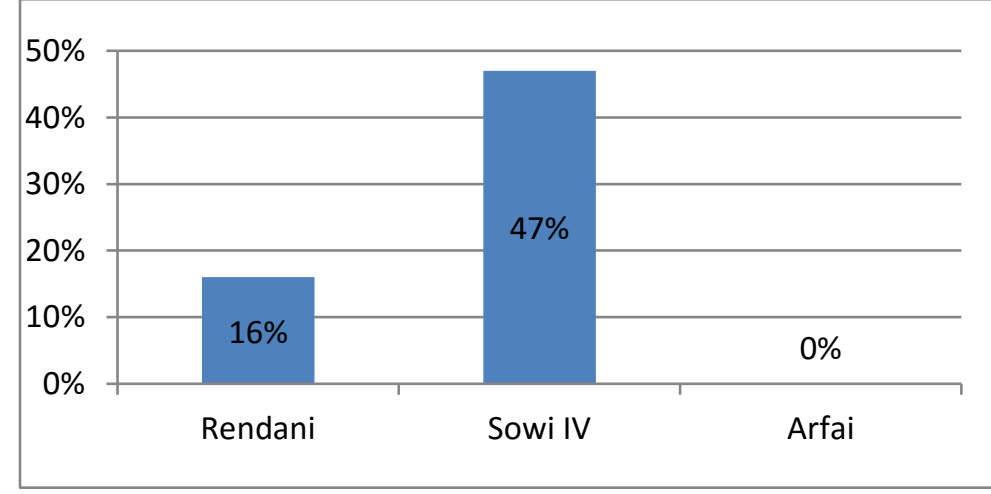

Gambar 2. Pemanfaatan mangrove sebagai bahan bangunan di Distrik Mansel 
Berdasarkan hasil wawancara, diperoleh informasi bahwa lebih dari separuh responden $(53 \%)$ di lokasi studi memanfaatkan kayu mangrove sebagai bahan bangunan (Gambar 2). Selain sebagai bahan bangunan, masyarakat juga memanfaatkan mangrove sebagai bahan bakar, bahan pembuatan naju perahu, dan sebagai daerah penangkapan ikan. Pada Gambar 3., tampak bahwa persentase responden yang menggunakan mangrove sebagai kayu bakar hampir sama dengan peman-faatannya sebagai bahan bangunan, yakni sebesar 55\% responden. Masyarakat pesisir yang umumnya memanfaatkan mangove se-bagai bahan bangunan dan bahan kayu bakar adalah masyarakat di Rendani dan Sowi IV. Masyarakat Sowi IV juga memanfaatkan batang pohon kayu mangrove sebagai naju perahu.

Meskipun mangrove disebutkan dapat menjadi bahan pangan dan obatobatan (Be-ngen, 2003, Priyono, $d k k$. 2010), peman-faatannya di lokasi studi masih sangat rendah. Lebih dari $90 \%$

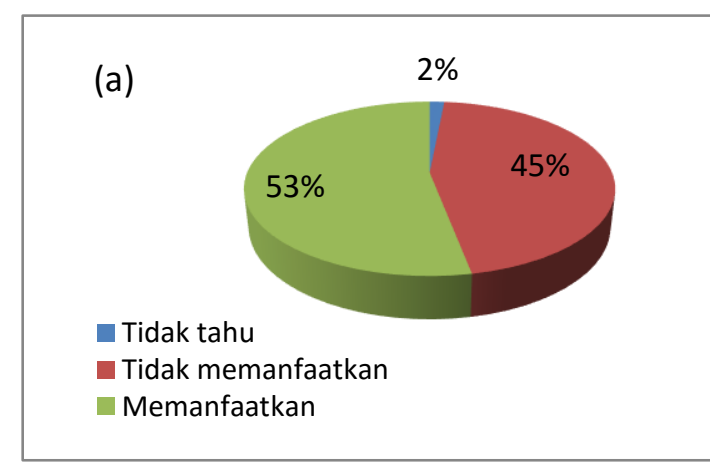

responden tidak mengetahui bahwa mangrove dapat dimanfaatkan sebagai bahan pangan dan obat-obatan (Gambar 4.). Hal ini disebabkan belum adanya pengetahuan masyarakat untuk mengolahnya, senada de-ngan pemaparan Budiharsono (2001) dalam Tuwo (2011), yakni bahwa potensi sumber-daya pesisir dan laut belum dimanfaatkan secara optimal oleh masyarakat karena kurangnya pengetahuan.

Terkait dengan lamun, umumnya responden menyatakan tidak tahu manfaat lamun (Gambar 5). Romimohtarto dan Juwana (2007) menyatakan bahwa secara tradisional lamun dapat dimanfaatkan untuk bahan anyaman, bahan baku garam, bahan pengisi kasur, bahan atap rumbia, bahan kompos, bahan isolasi suara dan suhu, bahan pengganti benang, bahan untuk tumpukan pematang, bahan cerutu dan mainan anak-anak. Namun hanya $3 \%$ responden di lokasi studi yang memanfaatkan lamun, yakni sebagai bahan pewarna dan lokasi budidaya rumput laut, selebihnya tidak paham dengan manfaat lamun.

Gambar 3. Pemanfaatan mangrove sebagai bahan bangunan (a) dan kayu bakar (b)

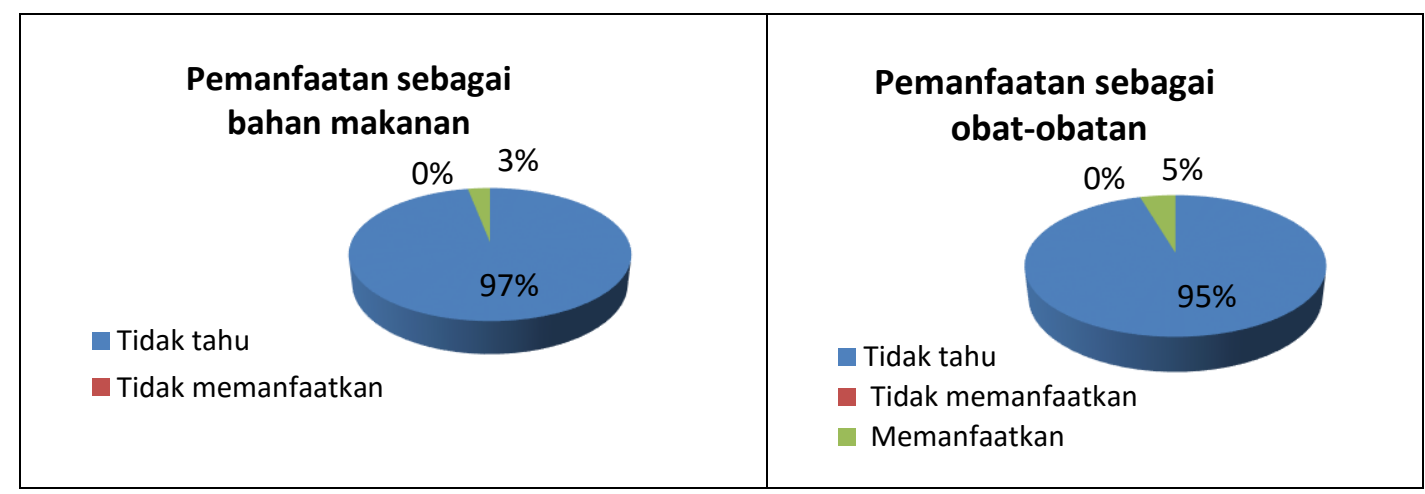

Gambar 4. Pemanfaatan mangrove sebagai bahan makanan dan obat obatan 


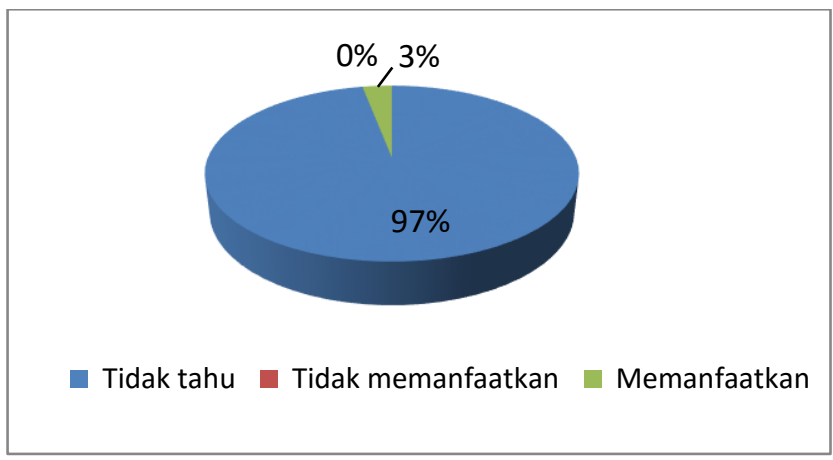

Gambar 5. Pemanfaatan lamun oleh masyarakat di lokasi studi

Seluruh responden memiliki mata pencaharian sebagai nelayan, baik nelayan penuh maupun sambilan, sehingga mereka meman-faatkan terumbu karang untuk menangkap ikan (100\%). Meskipun demikian, hanya $17 \%$ yang menilai terumbu karang bermanfaat sebagai penyedia lapangan kerja (Gambar 6).

Diduga bahwa sebagian responden masuk ke dunia penangkapan ikan dan men-jadikannya sebagai sumber pendapatan karena keterpaksaan dan profesi nelayan belum dianggap sebagai pekerjaan yang menjanjikan. Seluruh responden $(100 \%)$ juga tidak memanfaatkan terumbu karang sebagai objek wisata.

Meskipun memiliki ketergantungan yang cukup tinggi terhadap keberadaan terumbu karang, aktivitas pemanfaatan yang bersifat merusak juga masih dilaku- kan oleh responden. Pada Gambar 7, dapat dilihat bahwa masyarakat pesisir Kelurahan Sowi IV lebih dominan menggunakan karang untuk pondasi rumah jika dibandingkan dengan lokasi lain. Selain sebagai pondasi rumah pribadi, diperoleh informasi bahwa terdapat pula masyarakat yang mengumpulkan karang untuk dijual kepada kontraktor pembangunan talud di sepanjang pesisir Distrik Manokwari Selatan.

Masyarakat pesisir di lokasi studi juga memanfaatkan karang sebagai bahan pembuatan kapur, persentase pemanfaatan oleh responden dapat dilihat pada Gambar 8a. Umumnya responden yang mengetahui pemanfaatan karang sebagai bahan pembuatan kapur adalah responden di Sowi IV.

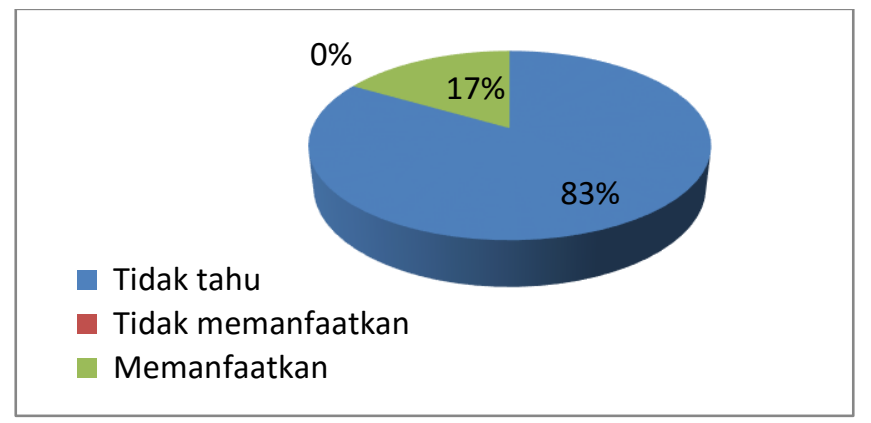

Gambar 6. Pemanfaatan terumbu karang sebagai penyedia lapangan kerja 


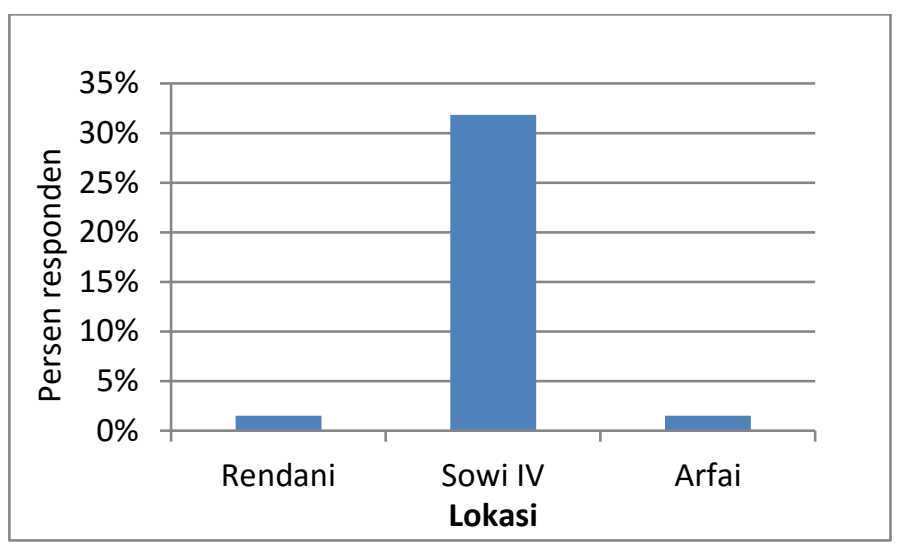

Gambar 7. Pemanfaatan karang sebagai bahan bangunan

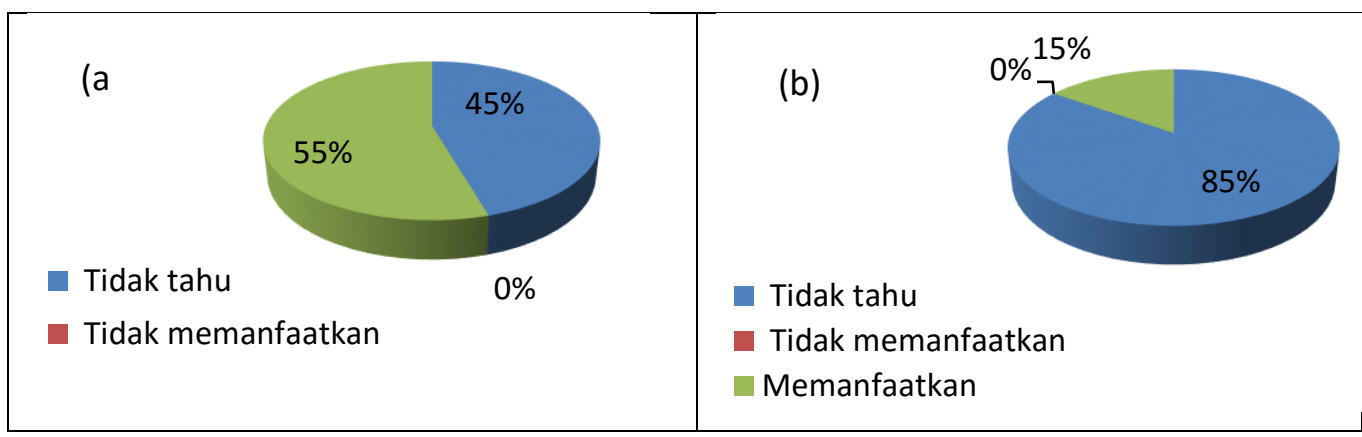

Gambar 8. Pemanfaatan terumbu karang untuk pembuatan kapur (a) dan pendidikan \& penelitian (b)

Terkait pemanfaatan terumbu karang untuk kegiatan pendidikan dan penelitian, di-peroleh informasi bahwa masih sedikit res-ponden yang paham akan manfaat ini. Hanya $15 \%$ responden yang memanfaatkannya sebagai sarana pendidikan dan penelitian, dan sisanya tidak paham (Gambar 8b). Selain dimanfaatkan sebagai sarana pendidikan oleh masyarakat setempat, pemanfaatan terumbu karang sebagai laboratorium pendidikan dan penelitian juga dilakukan oleh kalangan luar, seperti Perguruan Tinggi.

\section{Persepsi Masyarakat terhadap Pelesta- rian Ekosistem Pesisir}

Masyarakat yang berdomisili di pesisir pantai Rendani, Sowi IV dan Arfai memiliki persepsi terhadap lingkungan pesisir yang berbeda, namun secara keseluruhan, $100 \%$ masyarakat menilai bahwa wilayah pesisir di sekitar tempat tinggal mereka telah mengalami kerusakan dan membutuhkan upaya pelestarian.

\section{Persepsi masyarakat tentang permasa- lahan di pesisir}

Permasalahan lingkungan yang sangat menonjol di daerah pesisir adalah kerusakan hutan mangove dan terumbu karang (Tuwo, 2011). Demikian pula studi yang dilakukan oleh Irianto (2013) dan DKP Manokwari (2011) menunjukkan bahwa telah terjadi kerusakan ekosistem pesisir di sekitar perairan Raimuti dan Telaga Wasti Distrik Manokwari Selatan. Terkait dengan hal ini, penilaian yang sama juga diberikan oleh masyarakat setempat. Seluruh responden $(100 \%)$ bahkan menyebutkan bahwa kerusakan ekosistem pesisir, terutama mangrove dan terumbu karang, yang telah terjadi di wilayah mereka adalah masalah besar, meskipun dengan persentasi nilai yang berbeda (Gambar 9). Berkurangnya ikan dan biota lainnya, kontaminasi lautan oleh sampah, serta kehadiran nelayan dari luar yang mengambil hasil laut merupakan bentuk permasalahan di wilayah pesisir yang memperoleh persentasi ter- 
tinggi sebagai masalah besar. Sementara untuk pembangunan wila-yah pesisir di wilayah pesisir, hanya $58 \%$ yang menilai sebagai masalah besar. Sekitar 38\% responden tidak tahu bahwa pembangunan infrastruktur dapat menjadi masalah, sedangkan 3\% menilai bukan masalah.

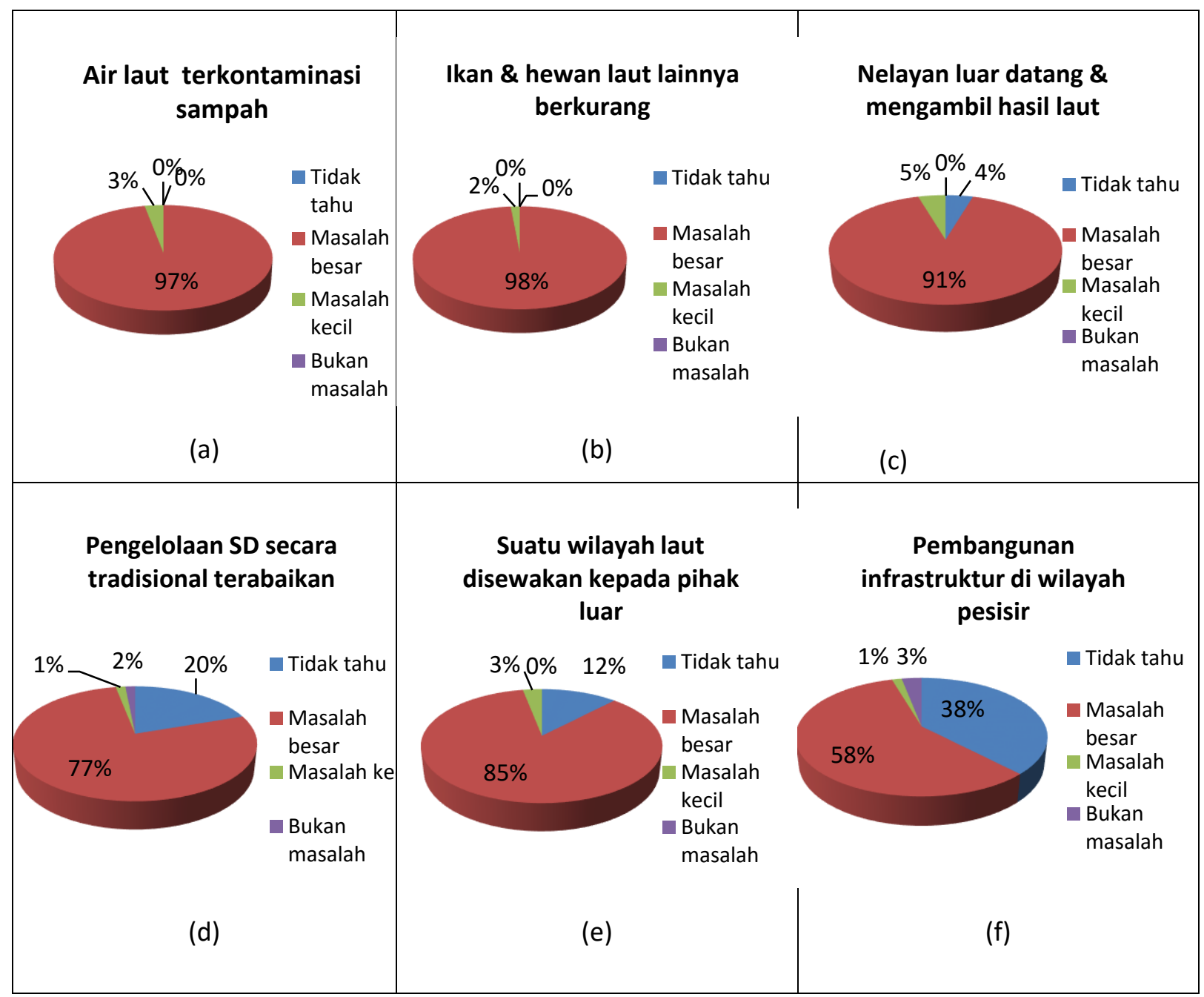

Gambar 9. Persepsi responden tentang permasalahan di wilayah pesisir Distrik Manokwari Selatan

\section{Persepsi Masyarakat tentang Kondisi Ekosistem Pesisir}

Ekosistem mangrove di Telaga Wasti Distrik Manokwari Selatan telah mengalami penurunan luasan, terutama karena aktivitas alih fungsi lahan (Irianto, 2013). Demikian pula dengan ekosistem mangrove dan terumbu karang di sekitar Pulau Raimuti dan Telaga Wasti (DKP Manokwari, 2011). Hasil studi tersebut serupa dengan penilaian masyarakat ter- kait kondisi ekosistem pesisir di wilayah mereka (Gambar 10).

Kondisi ekosistem mangrove dinilai buruk (97\%), jauh lebih tinggi dari jumlah responden yang menilai ekosistem terumbu karang buruk (83\%). Sebagian besar responden $(97 \%)$ juga menilai bahwa, kondisi mangrove dan terumbu karang lebih buruk dibandingkan dengan sepuluh tahun lalu (Gambar 11). 


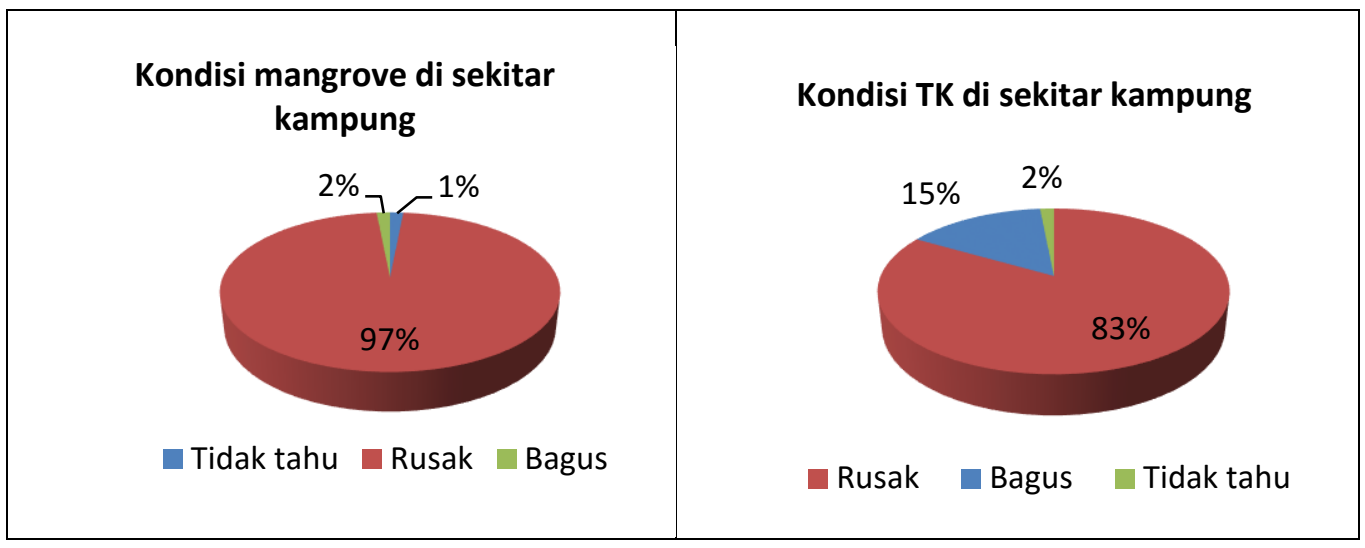

Gambar 10. Persepsi masyarakat tentang kondisi mangrove dan terumbu karang
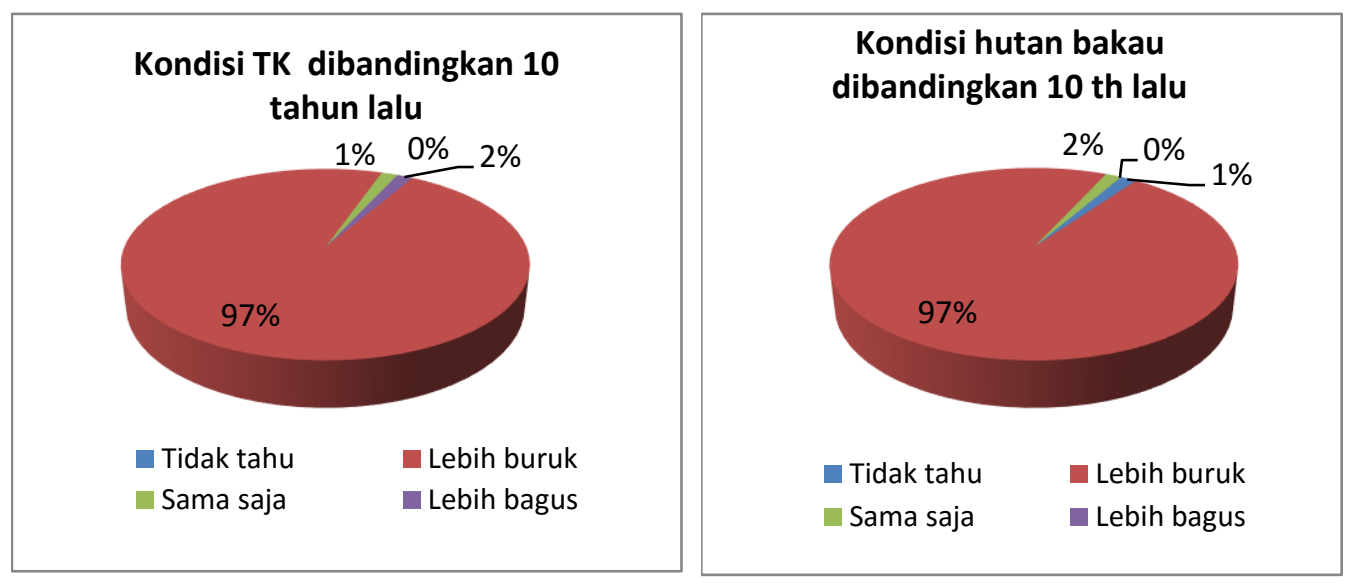

Gambar 11. Persepsi masyarakat tentang kondisi mangrove dan terumbu karang dibandingkan 10 tahun lalu

Responden juga menyebutkan bahwa rusaknya ekosistem pesisir di wilayah mereka sebagian besar disebabkan oleh kurangnya kesadaran masyarakat sendiri. Rusaknya eko-sistem mangrove dan terumbu karang di lokasi studi disebabkan karena penebangan mangrove, alih fungsi mangrove untuk pemukiman, pengambilan batu karang, dan pengeboman ikan. Selain itu, saat ini keberadaan pesisir juga terancam karena abrasi. Guna mengurangi dampak abrasi, saat ini pinggiran pantai Arfai juga dibangun talud.

\section{Partisipasi Masyarakat Nelayan dalam Upaya Pelestarian}

Responden di Rendani menyatakan bahwa terdapat kegiatan dari Dinas Lingkungan Hidup berupa penyuluhan tentang pentingnya menjaga ekosistem mangrove dan kegiatan penanaman mangrove di
Pantai Rendani, namun partisipasi masyarakat untuk mengikuti kegiatan tersebut rendah. Responden di Kelurahan Sowi IV aktif berpartisipasi dalam kegiatan penanaman mangrove yang dilaksanakan oleh Badan Lingkungan Hidup. Mitchell (2000) menyebutkan bahwa pelestarian ekosistem pesisir memiliki beberapa tahapan yang digunakan untuk perlindungan maupun pelestarian ekosistem pesisir, diantaranya adalah restorasi, reorientasi, responsivisivitas, rehabilitasi, responsibilitas, dan regulasi. Mengacu pada Mitchell (2000), kegiatan konservasi yang telah dilaksanakan di lokasi studi masih tergolong dalam level restorasi berupa upaya penghijauan. Terdapat pula ke-lompok Karang Taruna Abreso di Sowi IV, namun kegiatan yang dilakukan belum terkait dengan upaya konservasi. Kegiatan yang pernah dila- 
kukan oleh kelompok ini adalah pelatihan pembuatan abon. Di Kelurahan Arfai, terdapat kelompok nelayan Geropa Mandiri namun kegiatan yang dilakukan masih lebih dikhususkan untuk pembangunan rumah, fasilitas Mandi Cuci Kakus (MCK) dan jalan. Terdapat pula jenis kegiatan yang dilakukan oleh Kelompok Usaha Bersama (KUB) Nelayan, jenis kegiatannya adalah pembuatan rakit apung untuk mancing. Belum ditemui adanya upaya pelestarian ekosistem pesisir oleh masyarakat secara mandiri di lokasi studi. Kemandirian umumnya berlaku untuk kegiatan yang memberi manfaat ekonomi secara langsung.

Berdasarkan hasil wawancara, dipero-leh informasi bahwa ketiga faktor tersebut juga berlaku di lokasi penelitian. Umumnya responden mengharapkan peran kepala kampung dalam memimpin kegiatan konservasi. Pengetahuan tentang manfaat ekosistem peisir yang masih rendah juga menyebabkan kurangnya partisipasi masyarakat dalam pelestarian ekosistem pesisir. Responden juga menyebutkan bahwa sosialisasi terhadap program-program pelestarian lingkungan juga masih kurang.

Bunce et a.l (2000) menyatakan bahwa terdapat hubungan antara pemanfaatan sumberdaya dan kondisi sosial ekonomi masyarakat. Karena itu, salah satu upaya untuk meningkatkan peran masyarakat lokal dalam pengelolaan sumberdaya alam dan wilayah pesisir dan laut adalah dengan meningkatkan pengetahuan, keterampilan dan kesadaran masyarakat untuk berbuat sesuatu demi melindungi sumberdaya alam. Pengetahuan dan keterampilan tidak harus berkaitan langsung dengan upaya-upaya penanggulangan masa-lah kerusakan sumberdaya alam tetapi juga hal-hal yang berkaitan dengan usaha ekonomi, terutama dalam rangka membekali masya-rakat dengan usaha ekonomi alternatif se-hingga tidak merusak lingkungan, antara lain yaitu peningkatan pengetahuan dan wawasan lingkungan, pengembangan ketrampilan masyarakat, pengembangan kualitas diri, pening-katan motivasi masyarakat untuk berperan serta penggalian dan pengem- bangan nilai tradisional masyarakat (Primack et all, 1998)

Terkait dengan pengelolaan secara tradisional, hasil wawancara dari ketiga tokoh yang memiliki pengaruh di masyarakat yaitu tokoh masyarakat, tokoh adat dan tokoh agama, memberi informasi bahwa tidak ada upaya pengelolaan secara tradisional di wila-yah mereka. Umumnya responden adalah masyarakat yang datang dari luar wilayah dan tidak pernah memperoleh informasi tentang pengelolaan sumberdaya pesisir secara tradisional. Informasi tentang konservasi yang mereka dengar lewat sarana tempat beribadah juga tidak ada. Masyarakat juga mengatakan bahwa tidak ada batasan untuk wilayah pesisir itu sendiri dan tidak pernah dilakukan kegiatan sasi. Meskipun demikian, masih ada harapan untuk mendorong upaya pelestarian pesisir karena telah terbentuk kelompok nelayan dan karang taruna, yang dapat menjadi motor penggerak dalam upaya konservasi.

Adapun kegiatan yang umumnya diha-rapkan masyarakat dalam dua tahun ke depan adalah jenis kegiatan penanaman mangrove dan penanaman terumbu karang. Pada Gambar 12 tampak persentase responden tentang bentuk pelestarian ekosistem pesisir yang diharapkan dapat dilakukan ke depan.

Terkait dengan hubungan persepsi dan partisipasi masyarakat dalam pelestarian ekosistem pesisir, studi yang dilakukan Ayunita dan Hapsari (2012) menunjukkan bahwa ada hubungan yang kuat antara persepsi dan partisipasi masyarakat dalam pengelolaan kawasan konservasi. Pada Gambar 12 di atas, dan dengan membandingkannya pada persepsi masyarakat tentang permasalahan dan kondisi ekosistem pesisir, tampak bahwa kesadaran masyarakat tentang kerusakan ekosistem telah memberi kesadaran akan pentingnya pelestarian lingkungan. Hal ini terlihat dari tingginya pendapat bahwa penanaman mangrove merupakan kegiatan yang harus segera dilaksanakan (47\%). Hal ini dikarenakan ekosistem mangrove dinilai berada pada kondisi rusak oleh $97 \%$ responden. 


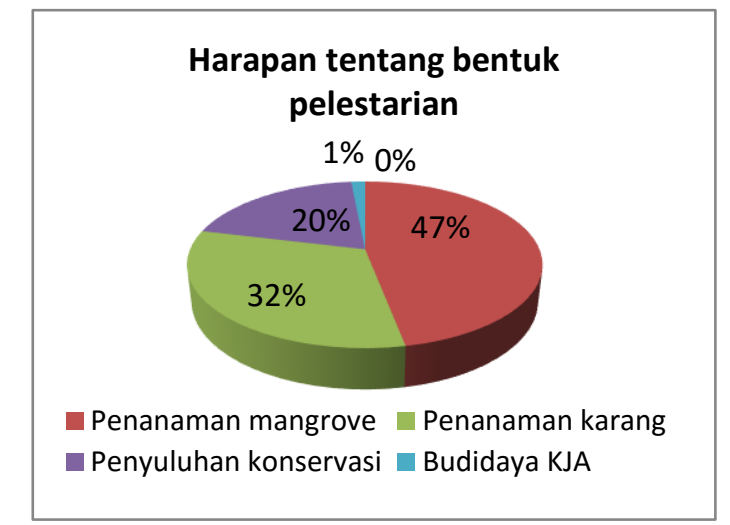

Gambar 12. Persentasi harapan masyarakat tentang bentuk pelestarian pesisir

Terkait dengan hubungan persepsi dan partisipasi masyarakat dalam pelestarian ekosistem pesisir, studi yang dilakukan Ayunita dan Hapsari (2012) menunjukkan bahwa ada hubungan yang kuat antara persepsi dan partisipasi masyarakat dalam pengelolaan kawasan konservasi. Pada Gambar 12 di atas, dan dengan membandingkannya pada persepsi masyarakat tentang permasalahan dan kondisi ekosistem pesisir, tampak bahwa kesadaran masyarakat tentang kerusakan ekosistem telah memberi kesadaran akan pentingnya peles-tarian lingkungan. Hal ini terlihat dari ting-ginya pendapat bahwa penanaman mangrove merupakan kegiatan yang harus segera dilaksanakan (47\%). Hal ini dikarenakan ekosistem mangrove dinilai berada pada kondisi rusak oleh $97 \%$ responden.

Mardijono (2008) memaparkan bahwa nelayan di pesisir Batam mempunyai tingkat persepsi sedang hingga tinggi terhadap arti pentingnya pengelolaan kawasan konservasi laut. Hal ini karena nelayan menyadari bahwa hasil tangkapan sangat tergantung kepada kondisi ekosistem yang baik. Tingkat partisipasi nelayan dalam kegiatan pelestarian terumbu karang dan mangrove tergolong sedang, sementara partisipasi dalam pengawasan rendah. Hal ini dikarenakan anggapan masyarakat bahwa sudah ada petugas yang ditunjuk untuk melakukan patroli penga-wasan. Diduga bahwa kondisi yang sama juga berlaku pada masyarakat pesisir di lokasi studi.

\section{KESIMPULAN}

Berdasarkan penelitian yang telah dila-kukan, maka dapat disimpulkan bahwa bentuk-bentuk pemanfaatan sumberdaya pesisir oleh masyarakat Distrik Manokwari Selatan, khususnya di Kampung Rendani, Kelurahan Sowi IV dan Kampung Arfai bervariasi. Umumnya masyarakat telah memanfaatkan mangrove dan karang sedangkan lamun belum dimanfaatkan. Terdapat bentuk-bentuk pe-manfaatan yang bersifat merusak kelestarian ekosistem pesisir seperti penebangan mangrove dan penambangan karang. Masyarakat memiliki kesadaran tentang kerusakan ekosistem pesisir yang terwakili oleh persepsi mereka dalam menilai bahwa kondisi lingkungan pesisir telah rusak, terutama ekosistem mangrove dan terumbu karang. Permasalahan yang paling dominan adalah berkurangnya sumberdaya ikan dan terkontaminasinya laut oleh sampah. Masyarakat juga menilai bahwa perlu ada upaya pelestarian sumberdaya alam pesisir dan lautan seperti penanaman mangrove dan penanaman karang. Upaya pelestarian yang pernah dilakukan adalah penanaman mangrove. Partisipasi masyarakat pesisir dalam pelestarian ekosistem pesisir tergolong rendah dan termasuk dalam partisipasi yang dimobilisasi. Masyarakat juga mengakui bahwa kesadaran mereka untuk me-lestarikan lingkungan masih rendah. Rendah-nya partisipasi diduga karena kurangnya kepemimpinan, pengetahuan dan komunikasi dari pihak-pihak yang lebih memahami konsep pelestarian.

\section{DAFTAR PUSTAKA}

Ayunita, D. dan T.D. Hapsari. 2012. Analisis Persepsi dan Partisipasi Masyarakat Pesisir pada Pengelolaan KKLD Ujung Negoro Kabupaten Batang. SEPA : Vol. 9 No.1 September 2012 : $117-124$ ISSN : 1829-9946 
DKP Manokwari, 2010, Survei Kondisi Terumbu Karang Pulau Raimuti dan Telaga Wasti. Dinas Perikanan dan Kelautan Kabupaten Manokwari.

Iriyanto. 2013. Struktur Komunitas gastropoda pada ekosistem mangrove di Telaga Wasti Sowi IVDistrik Manokwari Selatan Kab. Manokwari. Skripsi pada Program Studi Manajemen Sumberdaya Perairan Fakultas Peternakan Perikanan dan Ilmu Kelautan

Mardijono. 2008. Persepsi dan Partisipasi Nelayan terhadap Pengelolaan Kawasan Konservasi Laut Kota Batam. Tesis pada Program Magister Manajemen Sumberdaya Pantai. Universitas Diponegoro. Semarang.

Maulanawati R., 2013. Deteksi Laju Perubahan Garis Pantai di Teluk Doreri Manokwari. Skripsi pada Program studi Ilmu Kelautan Fakultas Peternakan Perikanan dan Ilmu Kelautan

Nikijuluw Viktor P.H. Politik Ekonomi Perikanan. 2005, Penerbit PT. Ferry Agung Corporation.

Opur F.F., 2013. Jenis Gastropoda Yang Berasosiasi Dengan Komunitas Mangrove, Lamundan Terumbu Karang di Perairan Pesisir Rendani Manokwari. Skripsi Pada Program Studi Manajemen Sumberdaya Perairan.

Priyono, A. Ilminingtyas, D. Mohson. Yuliani.S.L. Hakim.L. Tengku Juni 2010 Beragam Produk Olahan Berbahan Dasar Mangrove. Kerjasama Kesemat, DKP, Mangrove for the future dan IUCN.

Supriharyono, 2009, Konservasi Ekosistem Sumberdaya Hayati di Wilayah Pesisir Tropis, Penerbit Pustaka Pelajar, Yogyakarta.

Tuwo. A.H. 2011. Pengelolaan Ekowisata Pesisir dan laut: Pendekatan Ekologi, Sosial-Ekonomi, Kelembagaan dan Sarana Wilayah. Penerbit Brilian Internasional. 